\title{
MIR26A2 wt Allele
}

National Cancer Institute

\section{Source}

National Cancer Institute. MIR26A2 wt Allele. NCI Thesaurus. Code C81911.

The human MIR26A2 wild-type allele is located in the vicinity of $12 q 14.1$ and is approximately 83 bases in length. This allele, which encodes MIR26A2 pre-miRNA, plays a role in the regulation of gene expression. Alteration in the expression of this gene is associated with the development of cancers of the liver and thyroid as well as Burkitt lymphoma. 